\title{
POLITYKA IMIGRACYJNA PAŃSTW EUROPY ZACHODNIEJ. KAZUS LAMPEDUSY
}

\author{
Daria Orzechowska-Słowikowska \\ Polska Akademia Nauk, \\ Instytut Studiów Politycznych, Zakład Europeistyki \\ e-mail: dorzech@isppan.waw.pl
}

\begin{abstract}
Streszczenie. Lampedusa - niewielka wyspa położona na Morzu Śródziemnym, symbol udanego wypoczynku i rekreacji - taki opis pojawia się w katalogach reklamowych wielu biur turystycznych. Idylliczny obraz tej włoskiej wyspy jest zamazany przez setki zniszczonych łodzi z nielegalnymi uchodźcami na pokładzie. Od 2010 Lampedusa - oddalona o $150 \mathrm{~km}$ od wybrzeża Tunezji - jest głównym celem uchodźców z Afryki i Bliskiego Wschodu. Choć niemożliwe jest podanie dokładnej liczby nielegalnych imigrantów przebywających na terytorium Europy, wiadomo jednak, że państwa członkowskie Unii Europejskiej jednogłośnie sprzeciwiają się masowej migracji i zatrzaskują drzwi przed imigrantami arabskiej wiosny. Problem nie tkwi w tym, czy przyjmować imigrantów, ale w tym, jaką obrać politykę, aby zarówno imigranci, jak i państwa przyjmujące czerpały wzajemne korzyści.
\end{abstract}

Słowa kluczowe: nielegalni imigranci, polityka migracyjna, Lampedusa, Europa

\section{WSTĘP}

Napływ muzułmanów na włoską wyspę Lampedusa to polityczno-medialny lejtmotyw ostatnich kilku lat. Zdaniem badaczy procesów migracyjnych rok 2013 był rokiem inwazji imigrantów na Lampedusę. W roku 2013 z pierwszą podróżą poza region Rzymu papież Franciszek pojechał właśnie na Lampedusę, by spotkać się z imigrantami. Rząd Mario Montiego, ówczesnego premiera Włoch, odnowił umowę z Libią, zakładającą współpracę w przechwytywaniu nielegalnych imigrantów na Morzu Śródziemnym. Marine Le Pen, przywódczyni francuskiego Frontu Narodowego, rozpoczęła objazd krajów zachodniej Europy, aby jeszcze przed wyborami do Parlamentu Europejskiego, które odbyły się w maju 2014 r., nawiązać współpracę z ugrupowaniami narodowo-konserwatywnymi i eurosceptycznymi. Stefano Liberti, wielokrotnie nagradzany włoski reportażysta, wydał książkę pt. A sud di Lampedusa. Cinque anni di viaggi sulle rotte dei migranti 
(Na południe od Lampedusy. Podróże rozpaczy) o sytuacji uciekinierów z Afryki, usiłujących przedostać się nielegalnie do Europy.

Nie ulega wątpliwości, że w sprawie uchodźców z Afryki Północnej przebywających na Lampedusie państwa Europy Zachodniej mówią jednogłośne „nie”. Swą antyimigracyjną polityką udowadniają, że nie życzą sobie napływu kolejnych nielegalnych imigrantów na swoje terytorium. I choć zdają sobie sprawę z tego, że imigranci są trwałym składnikiem europejskiej rzeczywistości, systematycznie zaostrzają przepisy imigracyjne i apelują do przywódców Unii Europejskiej o wzmożoną kontrolę szlaków tranzytowych. Dane dotyczące populacji muzułmanów w Europie nie pozostawiają złudzeń. Restrykcyjne prawo imigracyjne to jedynie nieskuteczny straszak przeciw obcokrajowcom pochodzącym z państw muzułmańskich. Uszczelnienie granic przyczynia się do spadku liczby prób przedostania się do Europy, ale nie gwarantuje, że nie będą one ponownie podejmowane. Kazus Lampedusy uzmysławia nam aktualność tego problemu.

\section{NAPŁYW MUZUŁMANÓW DO EUROPY - DIAGNOZA I PROGNOZA}

Jednym z najważniejszych skutków arabskiej wiosny jest wzrost napływu imigrantów z państw Afryki Północnej i Bliskiego Wschodu do Europy. Z najnowszych danych Organizacji Narodów Zjednoczonych wynika, że w 2013 r.25\% populacji Marsylii i Rotterdamu stanowili muzułmanie, w Malmö mieszkało ich $20 \%$, a w Brukseli i Birmingham 15\%. Co najmniej trzy dzielnice w Londynie to dzielnice muzułmańskie, w Paryżu co najmniej cztery, nie licząc przedmieść, na których w 2007 r. doszło do brutalnych zamieszek. Coraz więcej muzułmańskich dzielnic powstaje także w Madrycie i w Amsterdamie, a w nich meczety, ośrodki nauki i kultury islamu oraz stowarzyszenia. ${ }^{1}$ Nikogo już obecnie nie dziwi, choć nadal bulwersuje widok muzułmanek szczelnie odzianych w burkę, nikab czy czador i przemierzających ulice zachodnioeuropejskich metropolii. Nie dziwią także meczety budowane w centrach europejskich stolic, restauracje serwujące wyłącznie dania halal $^{2}$ oraz bazary, zwane w języku arabskim suk.

Zmiany te wydają się na tyle trwałe, iż społeczeństwo państw przyjmujących musi zaakceptować to, że imigranci oraz elementy kultury islamu są składnikiem zachodnioeuropejskiej rzeczywistości, niemożliwym do usunięcia za pomocą restrykcyjnej polityki imigracyjnej oraz irracjonalnych przepisów utrudniających

1 Zob. M. Zawadewicz, Życie codzienne w muzutmańskim Londynie, Warszawa 2008; M. Arkoun, Histoire de l'islam et des musulmans en France du Moyen Âge à nos jours, Paris 2006; M. Widy, Życie codzienne w muzutmańskim Paryżu, Warszawa 2005; M. Nowaczek-Walczak, Życie codzienne w muzutmańskim Madrycie, Warszawa 2012; J. Zdanowski, Muzułmanie w Holandii, [w:] A. Parzymies (red.), Muzułmanie w Europie, Warszawa 2005, s. 423-432.

2 Halal - termin z zakresu prawa muzułmańskiego, którego używa się na określenie tego, co dozwolone. Termin ten odnosi się zarówno do potraw, rzeczy, osób, jak i do czynów. M.T. Tworuschka, Islam. Mały stownik, Warszawa 2005, s. 56. 
integrację nowo przybyłych z miejscowymi. Europa przegrywa ze światem islamu na polu demograficznym. Liczba muzułmanów napływających do Europy z roku na rok wzrasta, a atrakcyjność kontynentu europejskiego nie maleje. Czynnikiem spowalniającym napływ muzułmanów nie jest także, jak początkowo sądzono, kryzys ekonomiczny w Europie i związany z nim wzrost bezrobocia. ${ }^{3} \mathrm{~W}$ roku 2012 Europę zamieszkiwało 20 mln muzułmanów, w tym 14 mln państwa Europy Zachodniej. Oznacza to, że aż 5\% ludności Unii Europejskiej to wyznawcy islamu.

Lampedusa - do 2010 r. miejsce wypoczynku setek tysięcy turystów - obecnie kojarzona jest $\mathrm{z}$ nielegalnymi imigrantami pochodzącymi główne z państw Afryki Północnej, którzy wbrew wszelkim przeciwnościom losu i za wszelką cenę, nawet życia, próbują przedostać się do europejskiej „ziemi obiecanej”. Wydarzenia na Lampedusie stały się pretekstem do zaostrzania polityk imigracyjnych przez państwa Europy Południowej. Przeciwko napływowi muzułmanów z państw arabskiej wiosny coraz częściej opowiadają się także państwa Europy Północnej. Kazus Lampedusy stał się dowodem na to, iż imigracja kolejny raz stanowi wyzwanie dla Europy oraz wyzwanie łączące dwa brzegi basenu Morza Śródziemnego.

Tabela 1. Liczba muzułmanów w krajach Europy Zachodniej w 2012 roku

\begin{tabular}{|c|c|c|c|}
\hline \multirow{2}{*}{ Kraj } & \multicolumn{3}{|c|}{ Liczba ludności } \\
\cline { 2 - 4 } & \multirow{2}{*}{ calkowita w tys. } & \multicolumn{2}{|c|}{ w tym muzulmanie } \\
\cline { 3 - 4 } & & w tys. & w \% \\
\hline Francja & 65800 & $4000-5000$ & $7,0-8,0$ \\
\hline Niemcy & 81946 & 3200 & 3,4 \\
\hline Wielka Brytania & 63128 & 1591 & 2,7 \\
\hline Holandia & 16775 & 945 & 5,8 \\
\hline Włochy & 60861 & 700 & 1,2 \\
\hline Hiszpania & 47265 & 500 & 1,4 \\
\hline Belgia & 10839 & 400 & 4,0 \\
\hline Szwecja & 9546 & 350 & 3,9 \\
\hline Austria & 8443 & 340 & 4,2 \\
\hline Szwajcaria & 8014 & 311 & 4,1 \\
\hline
\end{tabular}

Źródło: $<$ http://epp.eurostat.cec.eu.int $>;<$ http://www.un.org/popin/data.html>.

Profil demograficzny państw Unii Europejskiej ciągle się zmienia. Według Organizacji Narodów Zjednoczonych w 2050 r. co piąty mieszkaniec Unii Europejskiej będzie muzułmaninem. Powyższe dane nie uwzględniają planów rozszerzenia Unii Europejskiej o Turcję liczącą $70 \mathrm{mln}$ wyznawców islamu. Europa stała się wielkim kotłem etnicznym, którego pojemność, jak dyplomatycznie podkreślają przywódcy prawicowych partii politycznych, została zminimalizowana.

3 D. Orzechowska, Kryzys ekonomiczny a decyzje migracyjne muzułmanów na przykładzie Francji. Diagnoza i prognoza na przyszłość, „Myśl Ekonomiczna i Polityczna” 2012, nr 3 (38). 
W świetle powyższych danych rodzi się pytanie dotyczące losów uchodźców z Afryki Północnej przebywających na Lampedusie. ${ }^{4}$ Francja, Włochy, Hiszpania oraz Wielka Brytania otwarcie sprzeciwiają się napływowi kolejnych fal uchodźców z państw Afryki i Bliskiego Wschodu ogarniętych wydarzeniami arabskiej wiosny. Nawet Niderlandy, jeszcze do niedawna uznawane za jedno z najbardziej liberalnych i tolerancyjnych wobec muzułmanów państw Unii Europejskiej, nie są zainteresowane losem uchodźców na Lampedusie. ${ }^{5} \mathrm{Z}$ kolei państwa, których problem nielegalnej imigracji nie dotyczy, lub dotyczy w minimalnym stopniu, mogą pomóc co najwyżej w budowie nowych ośrodków, ale imigrantów przyjmować nie chcą. I choć Unia Europejska argumentuje, że nielegalna imigracja jest sprawą jej wszystkich państw członkowskich, Europa Zachodnia systematycznie zaostrza prawo imigracyjne i kontrolę granic. ${ }^{6}$

Zaostrzenie nastrojów wobec przybyszów pochodzenia muzułmańskiego widać coraz wyraźniej także w Europie Południowo-Wschodniej. I trudno się temu dziwić, gdyż przez Bałkany Zachodnie przebiega jeden z głównych szlaków tranzytowych nielegalnych imigrantów. Zdaniem ekspertów z Europejskiej Agencji Zarządzania Współpracą Operacyjną na Granicach Zewnętrznych Państw Członkowskich Unii Europejskiej (Frontex), szlak przez centralną część Morza Śródziemnego, czyli na Lampedusę, Maltę oraz Sycylię, nie jest najpopularniejszą drogą, którą nielegalni imigranci próbują przedostać się do Unii Europejskiej. $\mathrm{W}$ pierwszej połowie $2013 \mathrm{r}$. dwiema największymi grupami nielegalnych imigrantów byli mieszkańcy Kosowa i Albanii. Dopiero na trzecim miejscu znaleźli się Libijczycy oraz Syryjczycy. Wśród osób, które w drugim kwartale 2013 r. ubiegały się o azyl w UE, dwukrotnie więcej było obywateli Rosji niż Syrii, a w pierwszej dziesiątce znaleźli się też mieszkańcy Kosowa i Serbii. ${ }^{7}$

Czy zatem w świetle danych Frontexu informacje o masowym napływie do Europy uchodźców z państw Afryki Północnej i Bliskiego Wschodu okazały się przesadzone? Jeszcze na początku $2011 \mathrm{r}$. straszono w europejskich mediach napływem ponadmilionowej fali imigrantów z krajów dotkniętych protestami. Obawy te były całkowicie nieuzasadnione. Nielegalna imigracja do krajów Unii Europejskiej od stycznia do października 2011 r. wyniosła ledwie 80 tys. W roku 2012 zwiększyła się do 130 tys. Z danych Biura Wysokiego Komisarza ds. Uchodźców (UNHCR) wynika, że w 2013 r. liczba nielegalnych imigrantów wyniosła 174 tys.,

${ }^{4}$ Kryzys na Lampedusie rozpoczął się w połowie marca 2011 r. W ciągu czterech dni na wyspę przypłynęło ponad 4 tys. imigrantów z państw Afryki Północnej. Wyspa o powierzchni $20,2 \mathrm{~km}^{2}$, licząca 5 tys. stałych mieszkańców, nie była przygotowana na przyjęcie tak dużej liczby imigrantów z państw Afryki Północnej.

5 P. M. Protasiewicz, Integracja z zachowaniem własnej tożsamości, Wrocław 2008.

6 Więcej w: C. Wihtol de Wenden, Faut-il ouvrir les frontières?, Presses de la Fondation Nationale des Sciences Politiques, Paris 2013.

7 Zob. Frontex, „Fran Quarterly” 2013, quarter 2, <http://frontex.europa.eu/assets/Publications/Risk_Analysis/FRAN_Q2_2013.pdf> (dostęp: 27.02.2014). 
a w 2014 r. do Europy próbowało się dostać 218 tys. nielegalnych imigrantów. ${ }^{8}$ Zdaniem ekspertów napływ imigrantów, zwłaszcza z państw Afryki Północnej i Bliskiego Wschodu, może trwać latami, zmieniać natężenie i skalę w zależności od rozwoju sytuacji w państwach objętych falą reform i demokratyzacji.

\section{KAZUS LAMPEDUSY}

Lampedusa to wyspa paradoksów. Z jednej strony miejsce pospolite. Zaledwie kilka wąskich uliczek przecinających się pod kątem prostym, ustawione szeregowo domy z tufu wulkanicznego, jednolita główna ulica ze wznoszącym się pośrodku ratuszem. Dwa lub trzy bary, z których jeden chwali się na wywieszonej tablicy: „Najbardziej wysunięty na południe lokal europejski”. ${ }^{9} \mathrm{Z}$ drugiej strony, jak podkreślają jej mieszkańcy, miejsce desantu niechcianych imigrantów z państw Afryki Północnej. Południowa brama starego kontynentu, skalisty przyczółek na drodze do Europy, stanowiący konieczny etap podróży dla tych, którzy przeprawiają się z Afryki przez morze. Ilu nielegalnym imigrantom udało się dopłynąć do brzegów Lampedusy? Trudno dokładnie stwierdzić. Szacuje się, że tylko w 2012 r. w ciągu zaledwie czterech miesięcy na Lampedusę - liczącą 5 tys. mieszkańców - przybyło ponad 40 tys. uchodźców z Afryki Północnej. Zdaniem ekspertów trudno także oszacować liczbę ofiar nieudanych przepraw ostatnich 20 lat, która oscyluje od 20 do 40 tys. Jak thumaczy António Guterres - Wysoki Komisarz ds. Uchodźców Organizacji Narodów Zjednoczonych, w samym tylko 2011 r. utonęło w morzu ponad 1,5 tys. osób, co niemal na pewno jest liczbą zaniżoną, bo obejmuje wyłącznie przypadki potwierdzone. ${ }^{10} \mathrm{Z}$ danych Biura UNHCR wynika, że w 2014 r. ponad 240 tys. nielegalnych imigrantów próbowało dostać się do Europy przez Morze Śródziemne, a co najmniej 3419 z nich zginęło w trakcie przeprawy. ${ }^{11}$ Jeśli wierzyć prognozom, to rok 2015 przedstawia się jeszcze tragiczniej. Dość powiedzieć, że o ile w styczniu i w lutym 2014 r. w wodach Morza Śródziemnego utonęło 15 nielegalnych imigrantów, w tym samym okresie 2015 r. zginęło ich już 450 tys.

W pojęciu badaczy migracji międzynarodowych Lampedusa jest miejscem tyleż legendarnym, ile tragicznym, do którego imigranci przypływają i przy które-

\footnotetext{
${ }^{8}$ Patrz: <http://www.unhcr-centraleurope.org/pl/index.html>.

${ }^{9}$ S. Liberti, Lampedusa, Włochy. Wyspa wyparcia, [w:] Na południe od Lampedusy. Podróże rozpaczy, Wołowiec 2013, s. 190.

${ }^{10}$ Zob. D. Orzechowska-Słowikowska, Siła islamu czy słabość Zachodu? Kierunki przemian społeczno-gospodarczych państw Unii Europejskiej, [w:] J. M. Fiszer (red.), System euroatlantycki $i$ bezpieczeństwo międzynarodowe w multipolarnym świecie. Miejsce i rola Polski w euroatlantyckim systemie bezpieczeństwa, Instytut Studiów Politycznych Polskiej Akademii Nauk, Warszawa 2013, s. 251-253.

${ }^{11}$ Więcej na ten temat: Asylum and Migration, <http://www.unhcr.org/pages/4a1d406060.html> (dostęp: 22.06.2015).
} 
go brzegach toną. ,Zwłoki, które codziennie wyrzuca morze na plaże Lampedusy, stały się zwykłym punktem dzienników informacyjnych, tak naturalnym jak odpływ i przypływ morza" - alarmowała w publicznej wypowiedzi burmistrz Lampedusy Giusi Nicolini. ${ }^{12}$ Ofiary tragicznych przepraw przez Morze Śródziemne chowane są w specjalnie wydzielonym miejscu jako non notus (nieznani). Na żadnej mogile nie ma tabliczki informującej o okolicznościach śmierci i tożsamości imigranta. Ci, którym udało się bezpiecznie dopłynąć na południowy przyczółek „Twierdzy Europa", jak nazywa Lampedusę Stefano Liberti, zostają umieszczani w ośrodku pobytu tymczasowego dla imigrantów w dzielnicy Imbriacola. Nie bez powodu Lampedusa nazywana jest ,jedynym we Włoszech miejscem bez imigrantów”. „My ich nigdy nie widzieliśmy. Zaraz po dotarciu na wyspę zabierają ich do ośrodka opieki"13 - thumaczy mieszkaniec wyspy w rozmowie ze Stefano Libertim.

Co interesujące, $z$ dostępnych danych statystycznych wynika, iż zmasowany napływ imigrantów z państw Afryki Północnej nastąpił właśnie na Lampedusę. Czy taki stan rzeczy jest wyłącznie skutkiem położenia geograficznego wyspy? Zdaniem Giusi Nicolini wzrost napływu imigrantów drogą morską na wyspę nie był ani dziełem przypadku, ani pochodną korzystnego oszacowania odległości, ale wynikiem ściśle określonej strategii, zaprogramowanej i sfinansowanej przez Rzym. „Celem włoskiego rządu była w pierwszej kolejności ochrona Sycylii oraz Pantellerii - wyspy VIP-ów. Wszystkie płynące ku wybrzeżom Sycylii łodzie, w tym również te, które pozornie zboczyły z kursu, kierowano na Lampedusę. W konsekwencji takich działań wyspa, która znajduje się bliżej wybrzeża afrykańskiego niż europejskiego, zyskała miano miejsca docelowego podróży imigrantów. Sprawne działanie tego mechanizmu leżało także w interesie Włoch, które dzięki temu radziły sobie z zagrożeniem imigracją i skupiły w jednym miejscu wszystkich imigrantów” - thumaczy dalej burmistrz Lampedusy. ${ }^{14}$ „Lampedusa” jawi się zatem jako mechanizm zarządzania problemem nielegalnej imigracji w polityce Włoch.

Do czasu wybuchu arabskiej wiosny Unia Europejska, a co za tym idzie Włochy, powierzyła kontrolę nad napływem imigrantów przez Morze Śródziemne swym sojusznikom z Afryki Północnej - pułkownikowi Muammarowi Kaddafiemu i egipskiej armii. W październiku 2007 r. Unia Europejska zawarła z ówczesnym przywódcą Libii umowę w sprawie „regulacji napływu nielegalnych imigrantów", co w praktyce oznaczało powstrzymywanie napływu Afrykanów do Europy. Punktem kulminacyjnym tej współpracy dotyczącej „kontroli imigrantów" było podpisanie w maju 2010 roku umowy z Kaddafim, w ramach której włoskie służby graniczne odsyłały schwytanych na morzu imigrantów do więzień w Libii, gdzie o ich dalszych losach miały decydować miejscowe władze. Poruszona tym faktem Unia Europejska ostentacyjnie skrytykowała premiera Silvio Berlusconiego za podejmowanie działań łamiących prawa człowieka. Oburzenie

\footnotetext{
${ }^{12}$ D. Rosiak, Więcej niż gest, „Tygodnik Powszechny”, 14 lipca 2013, nr 28.

${ }^{13}$ S. Liberti, Na poludnie od..., s. 188.

${ }^{14}$ Ibidem, s. 193.
} 
wyrazili także posłowie Parlamentu Europejskiego i sama Komisja. Jednakże w 2012 r. rząd Mario Montiego odnowił umowę z Libią, na podstawie której kontynuowano współpracę w przechwytywaniu nielegalnych imigrantów.

Wszyscy ludzie, którzy dopływają do wybrzeży południowej Europy, traktowani są z definicji jako „nielegalni”, dlatego też nikt ich nie chce - ani Włosi, ani Francja, ani ktokolwiek w Europie. Teza ta nie jest bezpodstawna. Zgodnie z prawem: przepisy europejskie wyraźnie wskazują, że obowiązek przyjęcia bądź utrzymania imigrantów spoczywa na kraju, do którego dotarli, a więc na Włoszech. Dla odmiany, Francja w 2011 roku zapowiedziała, że na jej terytorium, zgodnie z układem z Schengen, mogą przebywać tylko migranci mający ważny paszport i wystarczające środki finansowe, pozwalające na samodzielne utrzymanie. To warunki niemożliwe do spełnienia przez znaczną większość imigrantów napływających do Europy.

\section{OD KSENOFOBII DO ZAOSTRZANIA POLITYKI IMIGRACYJNEJ}

Już w drugiej połowie 2012 r. eksperci podkreślali, że polityka imigracyjna może stać się jedną z najważniejszych kwestii wyborów do Parlamentu Europejskiego (PE) w 2014 r. i wyborów parlamentarnych odbywających się w wielu krajach Europy. Przypuszczenia te w pełni się potwierdziły. We wrześniu 2013 r. Marine Le Pen rozpoczęła objazd krajów zachodniej Europy, aby jeszcze przed kampanią wyborczą do PE nawiązać współpracę z ugrupowaniami narodowo-konserwatywnymi i eurosceptycznymi, co przyniosło jej sukces z majowych wyborach do PE. Chodzi tu przede wszystkim o belgijski Interes Flamandzki (Vlaams Belang, VB), Partię Niepodległości Zjednoczonego Królestwa (United Kingdom Independence Party, UKIP), Brytyjską Partię Narodową (British National Party, BNP), partię Prawdziwych Finów (Perussuomalaiset, PS), włoski Ruch Pięciu Gwiazd Beppe Grilla (MoVimento 5 Stelle, M5S), Alternatywę dla Niemiec (Alternative für Deutschland, AfD) oraz niderlandzką Partię Wolności (Partij voor de Vrijheid, PVV). W roku 2009 Brytyjska Partia Narodowa została pozwana przez sąd o rasową dyskryminację za wprowadzenie zakazu wstępu do partii przedstawicielom mniejszości narodowych, religijnych, rasowych i etnicznych. Interes Flamandzki - sukcesor Bloku Flamandzkiego - został uznany za partię ksenofobiczną i rasistowską. Z kolei Niderlandzka Partia Wolności, podobnie jak francuski Front Narodowy, domaga się zatrzymania imigracji, zwłaszcza z krajów islamskich, a także sprzeciwia się rozszerzeniu Unii Europejskiej o kolejne państwa.

Każde z wymienionych ugrupowań jest partią skrajnie prawicową, nacjonalistyczną, eurosceptyczną, nierzadko odwołującą się do idei białej supremacji i faszyzmu. Każda z nich zyskuje coraz większe poparcie rozczarowanego i zbuntowanego społeczeństwa Unii Europejskiej, co pokazały wybory do PE z maja 2014 r. Oficjalnie w Brukseli mówiło się, że wybory do Parlamentu Europejskiego będą należeć do populistycznych przywódców eurosceptycznych partii politycznych i ta prognoza 
po części się sprawdziła. „Grozi nam najbardziej antyeuropejski Parlament Europejski w historii. [...] Z tak eurosceptycznym Parlamentem, jaki się szykuje, grozi nam paraliż. Dlatego wzywam do wielkiej batalii na rzecz »europeizmu« - Europy narodów przeciw Europie populistów" - alarmował Enrico Letta, ówczesny premier Włoch. Eurowybory dla polityków pokroju Marine Le Pen, Beppe Grilla czy Nigela Farage'a - przewodniczącego UKIP, to szansa na jeszcze większe wzmocnienie swojej pozycji jako populistycznych polityków na arenie międzynarodowej. Już dziś co czwarty Francuz popiera Front Narodowy, a co trzeci Włoch zagłosowałby na Ligę Północną lub Ruch Pięciu Gwiazd. Jeszcze na początku 2013 r. grecki neonazistowski Złoty Świt, który urządził obławę na dzielnice imigranckie, cieszył się w Grecji 14-procentowym poparciem. „Będziemy wygrywać bądź przegrywać z populistami w Europie także w zależności od tego, jak będziemy sobie radzić ze sprawą imigrantów" - apelował w publicznym wystąpieniu Letta. ${ }^{15}$

Unia Europejska nie radzi sobie z przybyszami pochodzenia muzułmańskiego, którzy kolejny raz staną się kartą przetargową dla polityków. Problem z imigracją obok bezrobocia jest jednym $\mathrm{z}$ głównych punktów zarówno wyborów lokalnych oraz kampanii prezydenckich, jak i wyborów do Parlamentu Europejskiego. Rządy Francji, Włoch i Wielkiej Brytanii nieustannie zapowiadają tworzenie dodatkowych miejsc pracy, zwłaszcza dla osób do 25 roku życia, jednocześnie nie potrafią skutecznie zahamować napływu nielegalnych imigrantów. We Francji w latach 20022011 aż siedem razy zaostrzono przepisy ustawy imigracyjnej. Nicolas Sarkozy, jeszcze jako prezydent Francji, wprowadził ,imigrację selektywną”, którą Marine Le Pen jednoznacznie nazwała „kretyńską koncepcją”. W Wielkiej Brytanii premier David Cameron zaapelował o ograniczenie rozmiarów imigracji o 75\%. Nawet w Niderlandach, jednym z najbardziej proimigranckich państw Europy Zachodniej, zaostrzono prawo imigracyjne. W roku 2011 kanclerz RFN Angela Merkel, dziękując Turkom za to, że za ich sprawą życie w Niemczech stało się bogatsze i różnorodniejsze, nie omieszkała jednak odnieść się do trudów wzajemnej integracji.

W październiku 2013 r. nowe, ostrzejsze prawo imigracyjne przegłosowała w drugim czytaniu brytyjska Izba Gmin. „Ograniczyliśmy już migracje zarobkowe spoza UE. Ukróciliśmy nadużycia wiz studenckich. Zreformowaliśmy przepisy dotyczące wiz rodzinnych. W rezultacie roczny bilans migracji spadł o jedną trzecią. Chcemy jednak, by do 2015 roku liczył się w dziesiątkach osób" - podkreśliła $\mathrm{w}$ jednej $\mathrm{z}$ wypowiedzi brytyjska minister spraw wewnętrznych Theresa May. ${ }^{16}$ Nowe prawo ma między innymi ułatwić ściganie nielegalnych imigrantów. Nie będą oni mogli otworzyć konta w banku ani legalnie wynająć mieszkania. W tym celu wynajmujący będą musieli sprawdzić status imigracyjny

${ }_{15}$ T. Bielecki i in., Czy ktoś rządzi Europa??, „Gazeta Wyborcza”, 01.11.2013; <http://wyborcza.pl/magazyn/1,134727,14882720,Czy_ktos_rzadzi_Europa_html> (dostęp: 05.11.2013).

${ }^{16}$ M. Kokot, M. Czarnecki, Europa ma już dość kolejnych imigrantów, „Gazeta Wyborcza”, 25.10.2013, <http://wyborcza.pl/1,76842,14839044,Europa_ma_juz_dosc_kolejnych_imigrantow.html> (dostęp: 12.12.2013). 
najemców. Brytyjczycy ograniczą osobom spoza Unii Europejskiej dostęp do bezpłatnej opieki medycznej (chyba że płacą one składki) i ułatwią deportację. May wydała też wojnę fikcyjnym małżeństwom i związkom partnerskim. Jak szacuje brytyjskie Ministerstwo Spraw Wewnętrznych, co roku od 4 do 10 tys. imigrantów wykorzystuje je, by ubiegać się o zezwolenie na pobyt w Wielkiej Brytanii. Antyimigracyjna ofensywa konserwatywnego premiera Davida Camerona to w dużej mierze odpowiedź na popularność ksenofobicznej Partii Niepodległości Zjednoczonego Królestwa. Reformie nie sprzeciwiła się nawet opozycyjna Partia Pracy, choć zapowiedziała serię poprawek. Dotyczyć one będą przede wszystkim walki z wyzyskiem nielegalnych imigrantów na rynku pracy.

Wielka Brytania to jedno z niewielu państw „starej” Unii Europejskiej, które rzeczywiście może pochwalić się skuteczną polityką imigracyjną. W roku 2012 bilans migracji - czyli różnica między osobami przyjeżdżającymi na Wyspy Brytyjskie a emigrującymi z nich - po raz pierwszy od sześciu lat spadł poniżej 200 tys. Zdaniem demografów restrykcyjna polityka imigracyjna oraz antymuzułmańskie działania populistów tylko częściowo zmniejszą liczbę muzułmanów w Wielkiej Brytanii. Nie ma wątpliwości, że Europa przegrywa na polu demograficznym ze światem islamu. Muzułmanki rodzą zdecydowanie więcej dzieci niż Brytyjki, które preferują model rodziny dwa plus dwa. Na zmianę profilu społecznego Wielkiej Brytanii, podobnie jak Francji, Hiszpanii i Niderlandów, wpływa również arabska wiosna. Wyraźny skutek arabskiej wiosny dla Europy - czyli wzmożony napływ imigrantów z państw Afryki Północnej i Bliskiego Wschodu - będzie trwały, zmieniając natężenie i skalę w zależności od rozwoju sytuacji w państwach objętych falą demokratyzacji, ale także od polityki imigracyjnej państw Unii Europejskiej.

\section{POLITYKA SZWAJCARII - „STOP MASOWEJ MIGRACJI”}

Ilu z tych, którzy dopłynęli na Lampedusę, zostanie deportowanych do swych ojczyzn, ilu obierze sobie za cel jedno z państw Europy Zachodniej, a ilu uda się na północ Europy? Monitorowanie skali migracji z państw Afryki Północnej do Europy z roku na rok jest coraz trudniejsze. Szacuje się, że ponad $20 \mathrm{mln}$ obywateli krajów arabskich mieszka poza swoimi ojczyznami. Do państw o największej liczbie imigrantów, których od $5 \%$ do $20 \%$ obywateli żyje za granicą, należą: Algieria, Maroko, Tunezja, Egipt, Libia, Syria, Liban, Palestyna, Jemen oraz Jordania. W samej tylko Europie Zachodniej zamieszkuje prawie $85 \%$ z niemal 700-tysięcznej tunezyjskiej diaspory, z czego połowa we Francji.

Francja nie jest jednak jedynym państwem borykającym się z napływem nielegalnych imigrantów z Afryki Północnej. Zdaniem demografów w wyniku arabskiej wiosny wzmożony napływ uchodźców odczuje, w mniejszym lub w większym stopniu, każde państwo europejskie leżące (zwłaszcza) w regionie Morza Śródziemnego. Wzrost napływu uchodźców z Afryki Północnej odnotowano w Grecji oraz w Portugalii. Przewiduje się również, że zwiększenie napływu 
uchodźców pochodzenia muzułmańskiego nastąpi także na wyspach Morza Śródziemnego należących do Unii Europejskiej. ${ }^{17}$ Casus Lampedusy mogą podzielić Malta i Sycylia, a zwłaszcza Cypr. Z uwagi na przynależność do Unii Europejskiej i położenie geograficzne Cypr, leżący we wschodniej części Morza Śródziemnego u wybrzeży Turcji, Syrii i Libanu, stanowi ziemię obiecaną dla setek tysięcy uchodźców, głównie z Bliskiego Wschodu. Ale czy jest on docelową destynacją imigrantów? Nie ulega wątpliwości, że większość (europejskich) wysp leżących na Morzu Śródziemnym, głównie ze względu na położenie geograficzne, stanowi dla uchodźców wyłącznie miejsce tranzytowe, z którego łatwo przedostać się na kontynent europejski. Problem w tym, że zarówno państwa członkowskie Unii Europejskiej, jak i te niebędące jej członkami mówią „nie” nielegalnym imigrantom, zamykając ich drogę na etapie tranzytu.

„Policzek wymierzony Europie”, ,najgorszy możliwy scenariusz”, „,woda na młyn eurosceptyków" - informowały nagłówki pierwszych stron europejskich gazet 10 lutego 2013. Powód? 9 lutego 2013 r. w wyniku referendum ponad połowa z 26 szwajcarskich kantonów i 50,3\% Szwajcarów, wbrew oczekiwaniom rządu, poparło ksenofobiczną inicjatywę „Stop masowej migracji” (Masseneinwanderung stoppen). Inicjator referendum, Szwajcarska Partia Ludowa (Schweizerische Volkspartei, SVP), z przewodniczącym Tonim Brunerem ${ }^{18}$, od kilku lat dąży do ograniczenia imigracji i postuluje ponowne negocjacje umów dwustronnych z Unią Europejską. „Imigracja ma być pod ścisłą kontrolą. Za konieczne zatem uważam wprowadzenie limitów dla wszystkich chcących przyjechać do Szwajcarii i tych, którzy już w tym kraju pracują" - postuluje Toni Brunner. ${ }^{19}$ Pierwszą i być może najważniejszą bitwę, choć z racjonalnego punktu widzenia kuriozalną, wygrali populiści. Udało im się przekonać Szwajcarów, że zatłoczone pociągi i uliczne korki to wina imigrantów, którzy co roku tłumie przybywają na terytorium tego niewielkiego państwa.

Szwajcaria kusi zarobkami i wysokim poziomem życia. Jak wynika z danych Szwajcarskiego Urzędu Statystycznego, w grudniu 2012 r. na terytorium Szwajcarii przebywało 1,8 mln obcokrajowców, to niemal 1/4 ludności Szwajcarii. ${ }^{20}$ Odsetek ludności napływowej (na terytorium Szwajcarii) jest jednym z najwyższych w Europie. Dla porównania w Austrii, Belgii czy w Szwecji wynosi on 15\%.

„Jeśli imigranci nadal będą napływać do kraju w takim tempie jak w drugiej dekadzie XXI wieku, to do $2060 \mathrm{r}$. Szwajcaria będzie liczyła nawet $16 \mathrm{mln}$ obywateli, czyli ponad dwa razy więcej niż w 2014 r." - thumaczy wiceprzewodniczący SVP

${ }^{17}$ Więcej C. Wihtol de Wenden, Atlas des migrations. Un équilibre mondial à inventer, Éditions Autrement, Paris 2012.

${ }^{18}$ Toni Brunner - ur. 23 sierpnia 1974 r. w Wattwil, polityk, przewodniczący Szwajcarskiej Partii Ludowej od 1 marca 2008 r., członek Rady Narodu od 1995 r.

${ }^{19}$ Zob. A. Kamińska, Imigranci dzielą Europę, „Bloomberg Businessweek”, 17-23 lutego $2014, \mathrm{nr} 7$.

${ }^{20}<$ http://www.bfs.admin.ch/bfs/portal/de/index/themen/01/02/blank/data/01.html > (dostęp: 10.03.2014). 


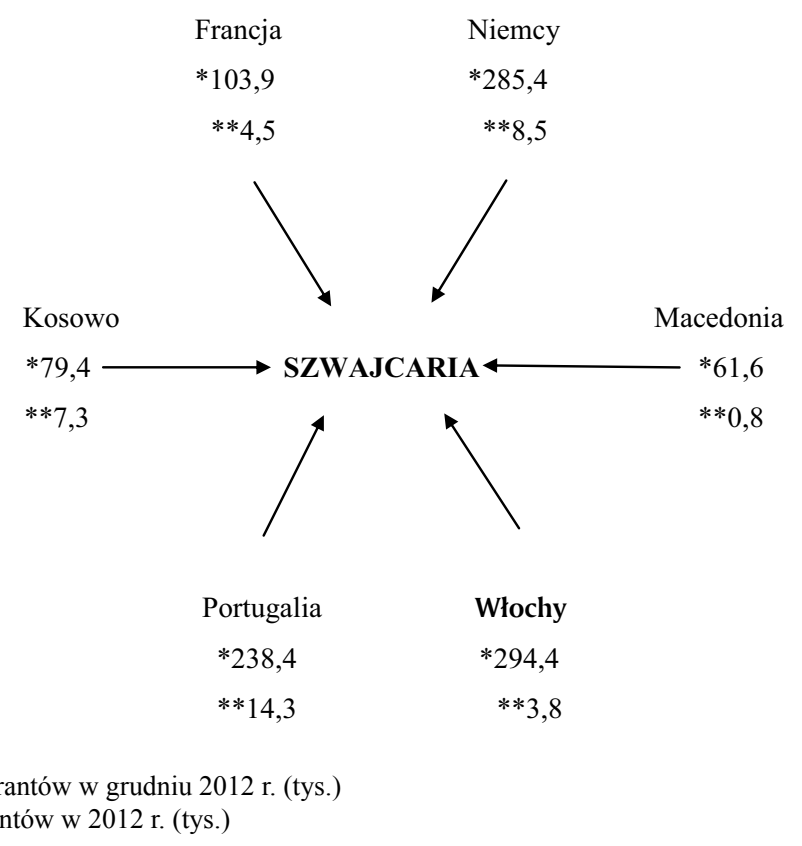

Schemat 1. Napływ imigrantów do Szwajcarii 2012 roku

Źródło: Opracowanie własne na podstawie: A. Kamińska, Imigranci dziela Europę, „Bloomberg Businessweek”, 17-23 lutego 2014, nr 7.

Christoph Blocker. ${ }^{21} \mathrm{~W}$ latach 2007-2010 liczba obcokrajowców mieszkających w Szwajcarii rosła średnio o ponad 52 tys. osób rocznie. Mimo obowiązujących ograniczeń tylko w 2013 r. do kraju przyjechało 80 tys. imigrantów. Falami napływają Francuzi, Hiszpanie, Włosi, Portugalczycy, Kosowarzy, Albańczycy i Turcy. To właśnie muzułmanie $\mathrm{z}$ uwagi na swe pochodzenie i religię najsilniej odczują konsekwencje referendum. Według danych ostatniego spisu ludności, przeprowadzonego w 2010 r., spośród ogólnej liczby mieszkańców państwa, wynoszącej $7 \mathrm{mln}$ 874 tys., prawie 400 tys. (około 4,5\%) jest muzułmanami. Wśród ogólnej populacji muzułmanów w Szwajcarii największą grupę tworzą wspomniani już Kosowarzy i Albańczycy (108 tys.), w mniejszym stopniu Macedończycy (43 tys.). Oprócz emigrantów z krajów bałkańskich terytorium Szwajcarii zamieszkuje 62 tys. Turków, ponad 4,5 tys. Marokańczyków, około 3 tys. Tunezyjczyków i Irakijczyków, ponad 2,5 tys. Algierczyków, niemal 1,3 tys. Libańczyków i poniżej tysiąca Egipcjan. ${ }^{22}$

To nie pierwszy raz, kiedy rząd Szwajcarii poległ w konfrontacji z populistami. W roku 2009 w wyniku referendum zorganizowanego z inicjatywy SVP

${ }^{21}$ Christoph Blocker - wiceprzewodniczący Szwajcarskiej Partii Ludowej, były biznesmen, właściciel jednego z koncernów chemicznych finansujących ksenofobiczne przedsięwzięcia partii.

${ }^{22} \mathrm{~K}$. Pędziwiatr, Od islamu imigrantów do islamu obywateli: muzulmanie w krajach Europy Zachodniej, Zakład Wydawniczy Nomos, Kraków 2005, s. 185-186. 
wprowadzono zakaz budowy meczetów z minaretami. Szala argumentów przeciw „dalszej ekspansji islamu” po raz kolejny przechyliła się na korzyść Szwajcarskiej Partii Ludowej. Za wprowadzeniem zakazu budowy minaretów opowiedziało się 57,5\% głosujących. Przeciw głosowały jedynie 4 z 26 kantonów. ${ }^{23}$ Działania szwajcarskiej partii prawicowej nie pozostawiają złudzeń. Muzułmanie nie są mile widziani zwłaszcza w dobie kryzysu gospodarczego. I choć bezrobocie w Szwajcarii wynosi zaledwie 3\% (średnia w UE około 11\%), a PKB na mieszkańca osiąga wartość 60,3 tys. euro (średnia unijna to 25,1 tys. euro) ${ }^{24}$, obcokrajowcy i tak są postrzegani jako konkurencja na rynku pracy. ${ }^{25}$ Do tego dochodzi jeszcze praca nielegalna. To powoduje, że antymuzułmańskie i ksenofobiczne przedsięwzięcia Szwajcarskiej Partii Ludowej zyskują coraz większą rzeszę zwolenników. Choć Unia Europejska deklaruje rolę mocarstwa cywilnego i reaguje na eskalację problemu uchodźców z Afryki (obligatoryjny system kwotowy), obecny kryzys humanitarny na południowej flance basenu Morza Śródziemnego (2015) może także spopularyzować takie rozwiązania w szerszym kontekście europejskim.

\section{ZAKOŃCZENIE}

Z dużym prawdopodobieństwem można założyć, że napływ muzułmanów z Afryki Północnej będzie trwał latami. Jak podkreślają demografowie, to dopiero początek exodusu uchodźców z państw Afryki Północnej na włoską wyspę. Wraz $\mathrm{z}$ narastającą liczbą imigrantów na Lampedusę postawa państw Europy Zachodniej radykalizuje się. Francja, Wielka Brytania i Włochy regularnie zaostrzają ustawy imigracyjne i nakładają limity. Otwarcie sprzeciwiają się przyjmowaniu kolejnych setek tysięcy uchodźców. Przywódczyni francuskiego Frontu Narodowego Marie Le Pen, przebywająca z wizytą w ośrodku dla uchodźców na Lampedusie, w marcu 2011 r.oświadczyła: „Europa nie może przyjąć wszystkich uchodźców. Byłoby nam miło zabrać każdego imigranta na naszą łódź, ale ona nie jest taka duża, pójdziemy na dno i my, i oni, dodamy biedę do biedy. Zamiast przyjmować ich na Lampedusie, Włochy powinny wysyłać statki z wodą oraz żywnością i pomagać imigrantom na morzu, nie dopuszczając do tego, żeby przybyli na wyspę". ${ }^{26}$ Le Pen nigdy nie ukrywała niechęci wobec muzułmańskich imigrantów w Europie. Uważa, że obowiązkiem Francji jest zaostrzanie polityki imigracyjnej w zależności od sytuacji gospodarczej kraju. Podobnego zdania są również inni liderzy ugrupowań narodowych z państw Europy Zachodniej.

${ }^{23}$ Zob. <http://www.bfs.admin.ch/bfs/portal/fr/index/themen/17/03/blank/key/2009/05. html> (dostęp: 14.03.2014).

${ }^{24}<\mathrm{http}$ ://appsso.eurostat.ec.europa.eu/nui/submitViewTableAction.do> (dostęp: 2.04.2014).

${ }^{25}$ Dla porównania: opiekunka osoby starszej pochodzenia muzułmańskiego zarabia miesięcznie około 1,5 tys. euro, czyli trzy razy mniej, niż zapłacono by Szwajcarce.

${ }^{26}$ Opération communication pour Marine Le Pen à Lampedusa, „Le Monde”, 14.03.2011. 
W przeciwieństwie do liderów skrajnie prawicowych partii politycznych Unia Europejska, która w 2012 r. otrzymała pokojową Nagrodę Nobla za „,kkuteczną walkę o pokój, pojednanie demokrację i prawa człowieka", nie ma nic do powiedzenia w sprawie tragedii, która ciągle rozgrywa się u brzegów „Twierdzy Europa". Analizując unijne dokumenty dotyczące napływu uchodźców z Afryki Północnej do Europy, łatwo wywnioskować, że nie wypracowano ani wspólnej polityki wobec imigrantów, ani systemu wczesnego ostrzegania o ruchach uchodźców, które mogłyby zaradzić tego typu tragediom. Bez względu jednak na postawę elit politycznych i Unii Europejskiej imigranci są stałym składnikiem europejskiej rzeczywistości, a Europa ich dożywotnim miejscem zamieszkania, w którym przestrzegają zasad religii i kultury islamu. Coraz większy udział muzułmanów w ogólnej populacji Starego Kontynentu powinien być wystarczającym powodem do tworzenia racjonalnej polityki imigracyjnej i integracyjnej.

\title{
IMMIGRATION POLICY OF WESTERN EUROPEAN STATES. THE CASE OF LAMPEDUSA
}

\begin{abstract}
Lampedusa - a small island situated in a Mediterranean tourist destination, a symbol of successful leisure and recreation - such a description appears in advertising catalogues in many tourist offices. This idyllic image has become blurred by hundreds of dilapidated boats full of illegal refugees. Since 2010, Lampedusa is the African refugees' main target for transfer to the European promised land. Even if it is impossible to assess the number of illegal immigrants who have made their way to Europe by sea or land after the Arab Spring, EU member states have decided almost unanimously to „stop mass migration” as a threat to European identity and security. But this self-interested logic has partially failed as the problem is how to help existing immigrant communities adapt to European values while accepting genuine refugees whose inflow is on the rise.
\end{abstract}

Key words: illegal immigrants, immigration policy, Lampedusa, Europe 